\title{
Global Business Review
}

http://gbr.sagepub.com

\section{Impact of Corporate Social Responsibility and Transformational Leadership on Brand Community: An Experimental Study \\ Karan Chaudhry and Venkat R. Krishnan \\ Global Business Review 2007; 8; 205 \\ DOI: $10.1177 / 097215090700800202$}

The online version of this article can be found at:

http://gbr.sagepub.com/cgi/content/abstract/8/2/205

\author{
Published by: \\ (5)SAGE Publications \\ http://www.sagepublications.com
}

Additional services and information for Global Business Review can be found at:

Email Alerts: http://gbr.sagepub.com/cgi/alerts

Subscriptions: http://gbr.sagepub.com/subscriptions

Reprints: http://www.sagepub.com/journalsReprints.nav

Permissions: http://www.sagepub.com/journalsPermissions.nav

Citations (this article cites 40 articles hosted on the

SAGE Journals Online and HighWire Press platforms):

http://gbr.sagepub.com/cgi/content/refs/8/2/205 


\title{
Impact of Corporate Social Responsibility and Transformational Leadership on Brand Community: An Experimental Study
}

\author{
Karan Chaudhry \\ Venkat R. Krishnan
}

\begin{abstract}
Not much work has been done to study the impact of various organizational variables on brand communities around various brands and consequently we have limited knowledge on how to build brand communities. Strong brand communities can be of tremendous value to organizations by generating increased customer loyalty towards their brands. This study attempts to examine the impact of corporate social responsibility and transformational leadership on brand community. The study employed a scenario based $2 \times 2$ experimental design, with corporate social responsibility and transformational leadership as the manipulated variables. The sample consisted of 118 graduate students doing the first year of their MBA programme in a leading management institute in India. Due to lack of availability of any standard measure, an instrument was developed to measure brand communities. Results of $2 \times 2$ factored analysis of variance show that brand community is enhanced by both corporate social responsibility and transformational leadership. The implications of these findings for firms and their top management are discussed.
\end{abstract}

There has been a growing interest in the field of brand community. It is felt that strong brand communities can be of tremendous value to organizations by generating heightened customer loyalty towards their brands. However, research in the area of brand community is still at a nascent stage. In this study, we examined the impact of corporate social responsibility and transformational leadership on brand communities. Corporate social responsibility is fast gaining importance as more and more firms realize its value. There is evidence to suggest that socially responsible actions of a firm enhance the brand image of the firms' products as well as the overall image of the firm. Hence, a positive

Karan Chaudhry is a student at the Graduate School of Business at Stanford University. E-mail: karanc@stanford.edu Venkat R. Krishnan is Professor of Organizational Behaviour at Great Lakes Institute of Management, Chennai 600015. Website: http://www.rkuenkat.org

Global Business Review, 8:2 (2007): 205-220

SAGE Publications Los Angeles/London/New Delhi/Singapore

DOI: 10.1177/097215090700800202 
relationship can be expected between corporate social responsibility and brand community.

Leadership qualities of managers have been a major area of interest in organizations across the world. Transformational leaders help followers see the importance of transcending their own self-interest for the sake of the mission and vision of their group or organization (Gardner and Avolio 1998; Shamir, House and Arthur 1993). Keeping this in mind, we felt that transformational leadership would be positively linked to brand community.

\section{Literature Review}

\section{Brand Community}

A brand community is a specialized, nongeographically bound community, based on a structured set of social relationships among admirers of a brand (Muniz and $\mathrm{O}^{\prime}$ Guinn 2001: p. 412). It, like other communities, is characterized by qualities like shared consciousness, rituals and traditions, and sense of moral responsibility. However, as it is centred around a branded good or service, everything is situated within a commercial and mass mediated ethos (Muniz and $\mathrm{O}^{\prime}$ Guinn 2001).

Bender (1978) described shared consciousness as a feeling of 'we-ness' among members. Shared consciousness refers to the inter-personal bonding, shared attitudes and perceived similarity between members of the community, and distinguishes them from others who are not a part of the community (Weber [1922] 1978). Rituals and traditions, like celebrating the history of the brand, advertisements, and sharing brand stories, are the vital social processes that evolve from the shared consumption experiences with the brand. They spread the community's shared history, culture, and consciousness, within and beyond the community. Moral responsibility refers to the feeling of responsibility or obligation among members, towards the community as a whole, and to its individual members. It spurs collective action leading to enhanced group cohesiveness (Muniz and O'Guinn 2001). Communities can be built around any brand ranging from expensive Harley Davidson to low cost Snapple. These generate intense loyalty based on real emotion and the members act as ambassadors of the brand. Contrary to the loyalty schemes, which lead to erosion of brand image in the long-term by lending commodity status, brand communities strengthen the brand image. Muniz and O'Guinn (2001) added that communities are most likely to form around visible publicly consumed brands with a strong image, rich heritage and threatening competition. The last aspect generates 'oppositional brand loyalty' among members, by further uniting the brand and its community members, leading to enhanced community experience and feeling of oneness. Identification with brand community leads to positive consequences such as greater community engagement (Algesheimer, Dholakia and Herrmann 2005).

Cova and Pace (2006) showed that the virtual community that gathers around a convenience product brand showed a new form of sociality and customer empowerment; it was not based on interaction between peers, but more on personal self-exhibition in front 
of other consumers through the marks and rituals linked to the brand. The study focused on a mass-marketed convenience product, while the literature on brand community has traditionally focused on communities born around niche or luxury brands like Harley Davidson, Mercedes and Saab. Prykop and Heitmann (2006) developed a procedure on how to design mobile brand communities according to perceived consumer value. They built on the four constituting elements of a community, which are member entities, shared interest, common space of interaction and relation, and combined them with the specific characteristics of the mobile channel, which are location awareness, ubiquity, identification and immediacy.

\section{Subcultures versus Brand Community}

Schouten and McAlexander's (1995) ethnography study on Harley Davidson riders demonstrated that riders derived an understanding of their brand through interaction with other users. This becomes a way of life or a subculture. Though a subculture has certain similarities with brand community, it is not the same as brand community. Subcultures build attitudes contrary to mainstream ideology whereas brand communities embrace it (Muniz \& O'Guinn 2001).

Brand communities differ from each other on geographic concentration, social context and temporality. Brand communities build customer relationship with the brand, firm, product and fellow customers. Research at Jeep Jamborees, Camp Jeep and Jeep 101 brand fests revealed that persons who exhibited weaker connection with the brand, firm, product and fellow customers before the fest, became significantly more connected after it. The overall feeling of integration in the Jeep brand community also increased. This provides marketers with a powerful tool to strengthen brand communities by facilitating shared customer experiences (McAlexander, Schouten and Koening 2002).

Brand Communities and Internet The Internet has become a powerful marketing medium in recent times. To build online communities, a firm has to build a site that provides participants with a forum for exchange of ideas, along with a sense of place with codes of behaviour. The firm has to encourage participation by as many people as possible to promote dialogue and relationships. This allows marketers to follow consumers' reactions and responses towards brands. Greater communication and interaction leads to better feedback and sense of community. This interactive online media will enable marketers to predict consumer behaviour with unprecedented accuracy and efficiency. One sensitive issue for organizations is to decide on how much control to exert over the content (McWilliam 2000).

Areas of concern Brand communities represent a form of consumer agency. They enable the consumers to have greater voice, more information and wider social benefits (Muniz and O'Guinn 2001). However, there exist some areas of concern. A strong brand community has the potential to threaten the marketer by rejecting marketing efforts and resisting product changes. Moreover, online communities can pose rumour control problems. Competitors can easily snoop on other brand communities and exploit their internal communication to subvert their values and 
attitudes. In addition, a strong brand community has the potential to signal brand marginality wherein the real essence of the brand might be lost (Muniz \& O'Guinn 2001). Goldman (2000) goes to the extent of calling the whole concept of brand community 'phony' as there are no checks and punishments and the whole concept is unrealistically upbeat and supportive.

Leadership abilities in the organization would play a crucial role in determining the success of efforts targeted towards creation and maintenance of brand communities. Transformational leadership could address some of the above-mentioned concerns, as transformational leaders are known to emphasize collective identity and place the collective goals at the top of their priorities. We look at transformational leadership in the next section to develop a better understanding of its impact on brand community.

\section{Transformational Leadership Transforma-} tional leadership occurs when leaders and followers raise one another to higher levels of motivation. Transformational leaders motivate followers to work towards selfactualization needs and transcendental goals (Bass 1998; Bass, Avolio and Goodheim 1987). Transformational leadership theory describes how a leader influences followers to make self-sacrifices, commit to difficult objectives and achieve more than expected (Ardichvili and Gasparishvili 2001). Transformational leadership brings about a complete transformation of followers over a period. Krishnan (2005) showed that relationship duration enhances the effect of transformational leadership on follower's terminal value system congruence and identification (cognitive outcomes), but not on attachment and affective commitment (affective outcomes).

According to Bass (1985), superior performance beyond normal expectations is possible only by transforming follower's values, attitudes and motives to a higher level of arousal and maturity. Transformational leaders exert long-term transformational influence over followers and provide ethical leadership by employing empowering strategies rather than control strategies. Empowering strategies increase the follower's capacity for self-determination (Bass and Steidlmeier 1999; Kanungo and Mendonca 1996). According to Keeley (1995), transformational leaders can be very effective ethical leaders. Transformational leaders aim at satisfying all the stakeholders in the organization. They try to balance the interests of the employees as well as the employer rather than sacrificing the individuals' interests for the sake of the organization (Bass 1997). Transformational leadership is characterized by qualities such as charisma, inspiration, intellectual stimulation and individualized consideration.

Over the last decade, empirical evidence has emerged linking transformational leadership to the implementation of largescale innovation programmes (Leithwood, Tomlinson and Genge 1996). To bring about change, authentic transformational leadership fosters the modal values of honesty, loyalty and fairness as well as the end values of justice, equality and human rights (Bass and Steidlmeier 1999). According to Bass (1985), transformational leadership is better for non-routine situations. Furthermore, Pawar and Eastman (1997) proposed that 
organizations would be more receptive to transformational leadership in situations where adaptation, rather than efficiency, is the goal.

Menguc, Auh and Shih (2007) presented transformational leadership and market orientation as managerial-based and transformational-based competencies respectively. Such competencies should lead to marketplace positional advantages through competitive strategies such as innovation differentiation, marketing differentiation and low cost. Jayakody and Sanjeewani (2006) showed that transformational leadership behaviour of salespersons enhanced the level of customers' trust and customers' relationship commitment with the salespersons. Fanelli and Misangyi (2006) extended the range of current transformational leadership theory beyond internal organizational members, linking CEO charisma to those outsiders key to organizational effectiveness: institutional intermediaries and external stakeholders. Flynn and Staw (2004) showed that charismatic leadership could influence external support for the organization particularly in making the company more attractive to outside investors.

\section{Transformational Leadership and Brand} Community A brand community, like other communities, is characterized by qualities like shared consciousness (we-ness among members), rituals and traditions, and sense of moral responsibility (Muniz and O'Guinn 2001). Transformational leadership transforms followers' self-interest into collective concerns and engages the full person of the follower (Burns 1978: p. 4). For Burns (1978), transformational leadership is moral in that it raises the level of human conduct and ethical aspiration of both leader and follower (p. 20). Transformational leaders help followers to see the importance of transcending their own self-interest for the sake of the mission and vision of their group or organization (Gardner and Avolio1998; Shamir, House and Arthur 1993).

A sense of community in the organization may sometimes prove to be a hindrance. The rigidity that accompanies the community feeling can hinder the change process required by the organization to adapt quickly to its business environment (Mehta and Krishnan 1999). A strong brand community has the potential to threaten the marketer by rejecting marketing efforts and resisting product changes (Muniz and O'Guinn 2001). Transformational leadership offers a solution to the above problem as it has been linked to the implementation of large-scale innovation programs (Leithwood, Tomlinson and Genge 1996). A transformational leader can ensure that the next generation of top management personifies the new approach by communicating how the changes have led to better performance (Kotter 1995). The leader appeals to the followers' need for achievement and growth by projecting the change in a manner that the followers find attractive. Hence, we hypothesized:

Hypothesis 1. Transformational leadership enhances brand community.

Another variable, which can have a significant influence on brand community is corporate social responsibility. It has been seen in the past that corporate social responsibility can help in creating competitive advantage, 
expressing corporate culture and improving long-term profitability (Albion 1991). Moreover, it has been seen that corporate social responsibility can attract customers by enhancing product, brand and company image (Owen and Scherer 1993). Hence, we look at corporate social responsibility in the next section to understand its impact on brand community.

\section{Corporate Social Responsibility}

Corporate social responsibility is a commitment by a business towards ethical behaviour, economic development and improvement in the quality of life of its workforce, their families, the local community and the society at large (Moir 2001). The underlying theme of corporate social responsibility is that business and society are interwoven rather than distinct entities (Wood 1991). Carroll (1979) in his three-dimensional corporate social performance model described four kinds of responsibilities namely economic, legal, ethical and discretionary (or volitional). Even though discretionary responsibilities are left to the business judgment and choice, social expectations do exist for businesses to assume greater responsibility over and above the explicit ones. Wartick and Cochran (1985) attempted to provide a theoretical foundation for Carroll's entire three-dimensional approach to corporate social performance as a set of social issues, response philosophies and corporate social responsibility categories. Moir (2001) discussed stakeholder theory, social contract theory and legitimacy theory to analyse and explain corporate social responsibility. Of these, stakeholder theory appears to be the most widely quoted in context of corporate social responsibility. Stakeholder theory suggests that a firm will assess its competitive position, evaluate strategies and monitor changes keeping in mind the interests of investors, consumers, suppliers, employees, government and society at large. Strategies that strengthen relationships with stakeholders create opportunities for sustainable competitive advantage and long-term profitability (Albion 1991).

Albion (1991) further stated that socially responsible actions play a crucial role in creating competitive advantage, expressing corporate culture and improving long-term profitability. This positive relationship between corporate social responsibility and firm financial performance is supported by several other studies (Cochran and Wood 1984; McGuire, Sundgren and Schneeweis 1988; Solomon and Hansen 1985). However, others suggest that firms incur costs from socially responsible actions that put them at an economic disadvantage as compared to other less responsible firms (Aupperle, Carroll and Hatfield 1985; Ullmann 1985). A study was conducted by Owen and Scherer (1993) to investigate the relationship between corporate social relationship and market share. The results suggested that of the nine issues considered, managers' perceived corporate actions related to environmental pollution, corporate philanthropy and disclosure of social information had the greatest impact on market share. Marin and Ruiz (2007) demonstrated that the corporate social responsibility contribution to company identity attractiveness is much stronger than that of corporate ability.

In several scenarios, corporate social responsibility has been manipulated to observe 
its effect on consumer behaviour. Lafferty and Goldsmith (1999) manipulated both endorser and corporate credibility in a hypothetical newspaper advertisement for athletic shoes. Corporate credibility was found to have a significant impact on attitudes toward both the advertisement and the brand, as well as on the purchase intention. Brown and Dacin (1997) studied the impact of corporate social responsibility by manipulating corporate philanthropy and community involvement and then asking the respondents to rate the firm and its products. The results showed that high corporate social responsibility led to a higher evaluation of the company, and corporate evaluation in turn had a positive impact on product evaluation. Murray and Vogel (1997) found that respondents had significantly more positive attitudes toward the company and more positive behavioural intentions, when the company's positive social programs were described. Moreover, these experiments demonstrate a strong negative impact of unethical or irresponsible corporate behaviours, which neutralizes and sometimes even dominates traditional purchase and selection criteria.

\section{Corporate Social Responsibility and Brands}

To enhance customer loyalty, a cause-related marketing programme should be well aligned with the company's social responsibility statement (Miller 2002). Various surveys conducted show that all other things being equal, increased level of social responsibility can actually attract customers (Owen and Scherer 1993). In a national survey, 45.6 per cent of the respondents said that they were likely to switch brands to support a firm that donates to charitable causes
(Smith and Alcorn 1991). In Cone/Roper 2001 Corporate Citizenship survey, 81 per cent of the Americans said that they were likely to switch brands when price and quality were equal, to help support a cause and 92 per cent of the Americans had a more positive image of the firms and products that support causes (Miller 2002). Willmott (2003) used the term 'Citizen Brands' to describe brands that engage in a proactive way with its society and citizens. He argued that brands are becoming detached from consumers, and the only way of realignment for brand owners is to incorporate more social values into their companies and their brands. Similarly, Blumenthal and Bergstrom (2003) described 'Brand Councils' as councils having the potential of highlighting the essential qualities and values of a brand by integrating all organizational activities under the umbrella of the brand. Corporate social responsibility needs to be integrated into the council to provide synergy, to help realize the brand promise, to maintain customer loyalty, to maximize the benefits of the investment that would be placed in corporate social responsibility regardless of the brand, and to avoid conflict with shareholders (Blumenthal and Bergstrom 2003). Biehal and Sheinin (2007) found that corporate messages transferred more than a product message onto other products in the company's portfolio. Moreover, a corporate ability message transferred more to the portfolio than did a corporate social responsibility message.

\section{Corporate Societal Marketing and Brand} Community Corporate societal marketing is one of the ways for a firm to be seen as socially responsible. Moreover, it is a tool that 
marketers can use to build brand communities. An effective way of building brand awareness and sense of community is to attach it to a social cause. The consumer's awareness and knowledge of the cause, its relevance to the brand, and the intensity of favourable association with the brand are the important considerations that should be kept in mind while selecting a cause. From a branding perspective, commonality and complementarity are the two paths for choosing a cause. Commonality refers to selecting a cause that shares common associations with the brand to reinforce existing brand image. Complementarity refers to the firm augmenting existing brand knowledge by associating with a non-profit cause to create a perceived differential advantage. Self-branding, cobranding and joint branding are the three corporate societal marketing branding alternatives. In self-branding, the firm takes ownership of a cause and creates a new organization to enjoy benefits. Co-branding sees the firm collaborating with an existing cause as a sponsor or supporter. Joint branding is a hybrid approach in which firms explicitly brand their programme that links to the existing cause (Hoeffler and Keller 2002).

It is clear that socially responsible actions of a firm can help enhance the brand image of the firms' products as well as the overall image of the firm. Moreover, corporate social responsibility appears to form an emotional link between the firm and its customers, both internal and external. This would not only generate higher loyalty, but could also create a sense of moral obligation amongst the customers.

Hypothesis 2. Corporate social responsibility enhances brand community.

\section{Method}

\section{Sample}

The data for the study were collected from a leading management institute in India. The sample for the study consisted of 118 first year MBA students. The sample consisted of 39 females and 79 males. Their age ranged from 21 to 26 years. The median age was 22 years. Their work experience ranged from 0 months to 4 years, the median work experience being 15 months.

\section{Procedure}

The respondents were divided into four groups or cells. We used a $2 \times 2$ (levels of transformational leadership [high, low] $\times$ levels of corporate social responsibility [low, high]) factorial design. Each cell was given a scenario to read. All the scenarios administered had a common introductory paragraph describing a fictitious firm, its vision, brand, products and a few other details. The later portions varied depending on the cell in which the scenario was being administered. Low transformational leadership cells had no additional material on the chief executive officer of the firm except for the brief mention in the introductory paragraph, whereas the scenario administered in the high transformational leadership cells had information that reflected the transformational leadership attributes of the chief executive officer. Moreover, the male actor enacting the role of the chief executive officer remained quiet in the low transformational leadership cells, and acted in accordance with his description provided to the respondents in the high transformational leadership cells. 
Similarly, in the low responsibility cells, the firms' focus on maximizing shareholder value was highlighted, whereas in the high responsibility cells, the firms' focus on abiding by law, ethical conduct, and charitable and philanthropic activities was prominent. At the end of the scenario, the respondents were instructed to assume that they were all regular customers of the firms' brand, and were divided into groups of five or six. They were then asked to give their inputs on the design of an advertisement for the brand in consideration. Once they were through, every respondent was administered a set of three questionnaires. The winners of the exercise were given gift hampers, while everyone received a token of appreciation for their participation. Finally, all the subjects were debriefed.

\section{Manipulated Variables}

The success of the experimental design manipulation was checked using two questionnaires, one for each manipulated variable. The first questionnaire was the 20-item Multifactor Leadership Questionnaire (Bass and Avolio 1995). Responses were measured along a 5-point Likert scale ( $1=$ Not at all; $2=$ Once in a while; $3=$ Sometimes; $4=$ Fairly often; 5 = Frequently, if not always). The second questionnaire consisted of the four dimensions of corporate social responsibility namely economic, legal, ethical and discretionary (Carroll 1979), measured using a 14-item forced choice format. The respondents were asked to distribute 10 points amongst the three or four choices attached to each item. This is a revised instrument based on the original 10-item instrument designed by Aupperle et al. (1985). The revised instrument retained the 10 core items and had four additional sets that were included in order to provide additional insights into an organization. The extra items were intended to reduce respondent social desirability bias by making the test taker feel that the instrument is more than just a survey about corporate social responsibility.

\section{Brand Community Questionnaire}

The questionnaire for measuring our outcome variable included a scale for brand community comprising six dimensions, which was developed by us based on inputs from McAlexander, Schouten and Koening (2002), and Mehta and Krishnan (1999). The questionnaire items are included in the Appendix. Responses were measured along a 5-point Likert scale ( $1=$ Not at all; $2=$ Once in a while; 3 = Sometimes; 4 = Fairly often; $5=$ Frequently, if not always). A pre-test was conducted using a sample of 31 graduate students currently in the second year of their MBA programme. The sample consisted of 7 females and 24 males in the age group of 21-27 years, the median age being 24 years. Their work experience ranged from 0 months to 46 months, the median work experience being 23 months. Two methods, namely questionnaire administration and personal interview were employed. The respondents were asked to fill up the questionnaire based on their perception about soft drink as the product, Coca-Cola as the brand, and Coke as the firm. Simultaneously, they were interviewed to gauge their perception about the six dimensions of brand community with respect to the above product, brand and firm. Scores were given by the interviewer on the six dimensions based on the responses given during 
the interview. The pre-test results, using bivariate correlation between the questionnaire scores and the interview scores, gave correlation coefficient greater than 0.7 for all the dimensions.

\section{Reliability and Manipulation Checks}

A reliability test was conducted for all three instruments used in the experiment. The Cronbach alpha for all the dimensions was found to be greater than 0.7, except for the 'rituals and traditions' dimension of brand community which had an alpha value of 0.58 .

The manipulation check revealed that all five dimensions of transformational leadership were significantly higher in the high transformational leadership cells as compared to the low transformational leadership cells. With respect to corporate social responsibility, all four dimensions of corporate social responsibility were significantly higher in the high corporate social responsibility cells as compared to the low corporate social responsibility cells.

\section{Results}

We tested for differences in brand community scores across the high and low transformational leadership and the high and low corporate social responsibility cells, using a $2 \times 2$ factor analysis of variance (ANOVA). Results are presented in Table 1 . There was a significant main effect of transformational leadership on the overall composite score and all the six dimensions of brand community. Brand community was significantly higher in the high transformational leadership cells as compared to the low transformational leadership cells thus providing support for our first hypothesis.

There was a significant main effect of corporate social responsibility on the overall composite score and all the dimensions of brand community except 'shared culture'. Brand community, except the 'shared culture' dimension, was significantly higher in the high corporate social responsibility cells as compared to the low corporate social responsibility cells thus providing support for our second hypothesis.

The interaction effect of transformational leadership and corporate social responsibility was not significant on any of the outcome variables. Thus, while transformational leadership and corporate social responsibility separately enhanced brand community, the simultaneous presence of both did not have any significant additional effect.

\section{Discussion}

Results provide support for both the hypotheses. As expected, both transformational leadership and corporate social responsibility enhance brand community. All dimensions and the composite score of brand community were found to be significantly higher in high transformational leadership cells than in low transformational leadership cells. Transformational leadership leads to the generation of a strong brand community, which can prove to be useful for a firm by guaranteeing loyal customers over a longterm horizon. 


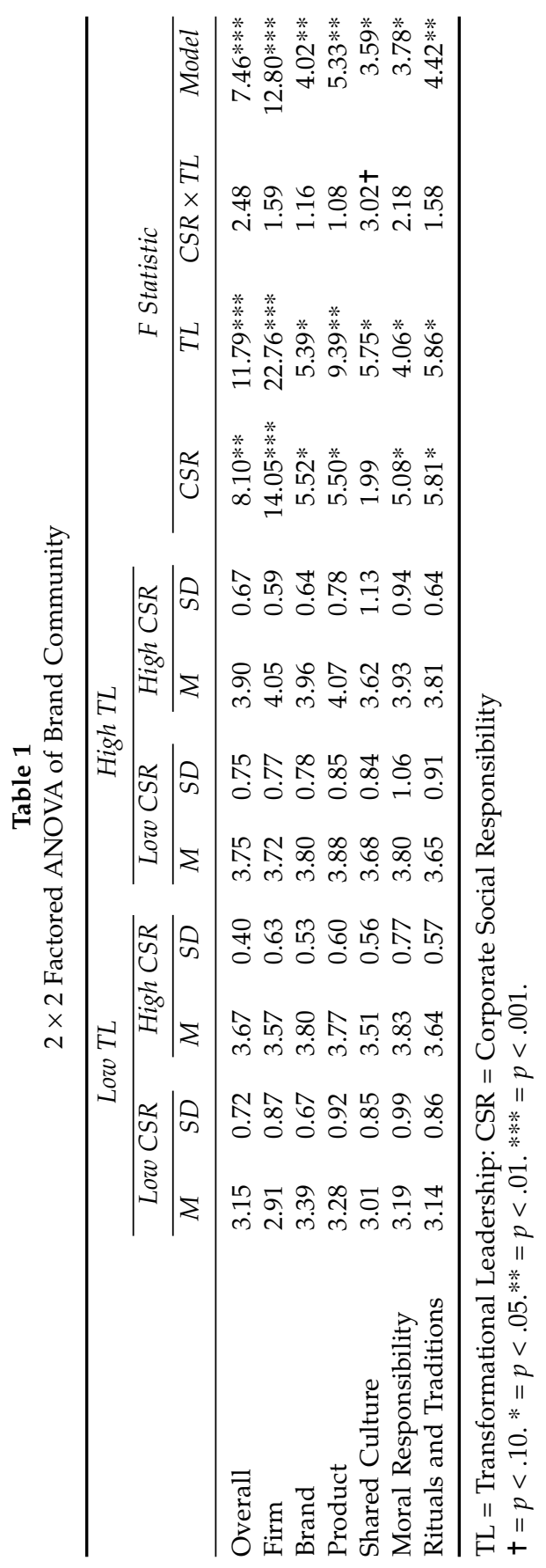


Corporate social responsibility is known to enhance the perception about the quality of the product, brand and firm. Moreover, according to the reciprocity principle, firms' association with philanthropic activities should increase customers' moral obligation towards the firm. Finally, the customer would expect the firm to act in a manner consistent with its image, and would start associating certain expected actions with traditions.

Finally, an effort was made in this study to quantify brand community by developing an instrument to measure it. Researchers are encouraged to refine the instrument by using it in future studies. Moreover, its validity across different population samples and situations should be tested.

\section{Managerial Implications}

Results of the present study have several implications for practicing mangers. It needs to be mentioned here that the study is especially relevant to firms with well-established brands, which enjoy high levels of brand loyalty.

First, it shows that transformational leadership can play a vital role in the development of a strong brand community. Thus, transformational leadership characteristics of a person could be incorporated as criteria for external recruitment or internal promotion to senior level management positions. Moreover, it also highlights the importance of projecting the desirable characteristics of the firms' senior managers in public, making the role of public relations all the more important.

Second, it shows that corporate social responsibility is becoming more of a necessity by the day. It is very important to the way the firm is perceived by the customers, and becomes all the more important to firms facing stiff competition. There are a couple of things, which need to be mentioned about corporate social responsibility. First, corporate social responsibility is not just about abiding by law but extends to ethical and volitional activities of the firm as well. Even though discretionary responsibilities are left to the businesses' judgment and choice, social expectations do exist for businesses to assume greater responsibility over and above the explicit ones (Carroll 1979). Second, it is essential that the socially responsible activities of the firm be well aligned with the brand image and the business goals of the firm (Hoeffler and Keller 2002). This would help reduce dissonance in the minds of the consumers, thereby increasing the chances of the efforts being perceived as genuine. Moreover, this would also ensure the long-term sustenance of these activities, as they directly compliment the firms' business goals. All this leads to the conclusion that the corporate social responsibility programme should be well thought out from multiple perspectives before going ahead with it, else it could negatively affect firm's image and lead to wasteful expenditure.

\section{Limitations and Suggestions for Future Research}

Several limitations of this study offer avenues for future research. These include the sample characteristics, the experiment design and several relevant parameters not examined in the current study. The relatively small homogeneous sample $(\mathrm{N}=118)$ consisted of fairly young graduate students (median age $=22$ years) with little work experience (median work experience $=15$ months), who would 
generally have a higher level of understanding of the above researched concepts compared to an outsider. These sample characteristic may limit the generalizability of our findings. Thus, future research could focus on replicating the study across different cultures with a larger and more diversified sample. The generalizability of the instrument designed by us also needs to be validated across different samples, especially because one of the dimensions (rituals and traditions) had an alpha value of 0.58 . The instrument can be further refined in future researches. Moreover, the research suffers from the inherent drawback of scenariobased experiments. The respondents were asked to fill all the three questionnaires simultaneously with no time lag between filling of the various questionnaires. Thus, it is recommended that longitudinal field studies be conducted on firms to get better results. The studies should consider the impact of various parameters such as size, age, and the industry to which the firm belongs. The impact of the stage of the product in the product life cycle should also be considered while conducting the field studies.

Moreover, the impact of individual dimensions of transformational leadership and corporate social responsibility could be focused on in future researches. This is especially relevant as abiding by law is not the same as ethical or philanthropic behaviour.

Finally, we believe that there is tremendous scope for future research in the area of brand community. Future research exploring the impact of other variables, like corporate citizenship behaviour and promotional activities of the firm, on brand communities should be encouraged. This information can be of tremendous help to organizations striving for the next step beyond brand loyalty.

\section{Conclusion}

The present study makes important contributions to the literature. First, it provides an instrument to measure brand community. Second, it shows the relevance and need of transformational leadership for positively influencing external customers and building a strong brand community. Finally, it reiterates the growing need for meaningful and well thought out corporate social responsibility programme to enhance the image of the firm on various aspects of long-term importance. As more studies provide further support to our findings, our understanding of brand communities would increase and building brand communities would become easier.

\section{REFERENCES}

Albion, M. 1991. 'Corporate Responsibility', Executive Excellence, 8(4): 13-15.

Algesheimer, R., U.M. Dholakia and A. Herrmann. 2005. 'The Social Influence of Brand Community: Evidence from European Car Clubs', Journal of Marketing, 69(3): 19-34.
Ardichvili, A. and A. Gasparishvili. 2001. 'Leadership Profiles of Managers in Post-communist Countries: A Comparative Study', Leadership and Organization Development Journal, 22(2): 691.

Aupperle, K., A. Carroll and J. Hatfield. 1985. 'An Empirical Examination of the Relationship Between 
Corporate Social Responsibility and Profitability', Academy of Management Journal, 28(2): 446-63.

Bass, B.M. 1985. Leadership and Performance Beyond Expectations. New York: Free Press.

- 1997. 'Does the Transactional/transformational Leadership Transcend Organizational and National Boundaries?', American Psychologist, 52(2): 130-39.

- 1998. Transformational Leadership: Industrial, Military, and Educational Impact. Mahwah, NJ: Lawrence Erlbaum Associates.

Bass, B.M. and B.J. Avolio. 1995. Multifactor Leadership Questionnaire. Redwood City, CA: Mind Garden.

Bass, B.M. and P. Steidlmeier. 1999. 'Ethics, Character, and Authentic Transformational Leadership Behavior', Leadership Quarterly, 10(2): 181-217.

Bass, B.M., B.J. Avolio and L. Goodheim. 1987. 'Biography and the Assessment of Transformational Leadership at the World Class Level', Journal of Management, 13(1): 7-19.

Bender, T. 1978. Community and Social Change in America. New Brunswick, NJ: Rutgers University Press.

Biehal, G.J. and D.A. Sheinin. 2007. 'The Influence of Corporate Messages on the Product Portfolio', Journal of Marketing, 71(2): 12-25.

Blumenthal, D. and A.J. Bergstrom. 2003. 'Brand Councils That Care: Towards the Convergence of Branding and Corporate Social Responsibility', Journal of Brand Management, 10(4/5): 327-41.

Brown, T.J. and P.A. Dacin. 1997. 'The Company and The Product: Corporate Associations and Consumer Product Responses', Journal of Marketing, 61(1): 68-84.

Burns, J.M. 1978. Leadership. New York: Harper \& Row. Carroll, A.B. 1979. 'A Three-dimensional Conceptual Model of Corporate Performance', Academy of Management Review, 4(4): 497-505.

Cochran, P. and R. Wood. 1984. 'Corporate Social Responsibility and Financial Performance', Academy of Management Journal, 27(1): 42-56.

Cova, B. and S. Pace. 2006. 'Brand Community of Convenience Products: New Forms of Customer Empowerment-The Case "My Nutella The Community"', European Journal of Marketing, 40 (9/10): 1087-1105.

Fanelli, A. and V.F. Misangyi. 2006. 'Bringing out Charisma: CEO Charisma and External Stakeholders', Academy of Management Review, 31(4): 1049-61.
Flynn, F.J. and B.M. Staw. 2004. 'Lend Me Your Wallets: The Effect of Charismatic Leadership on External Support for an Organization', Strategic Management Journal, 25(4): 309-30.

Gardner, W.L. and B.J. Avolio. 1998. 'The Charismatic Leadership: A Dramaturgical Perspective', Academy of Management Review, 23(1): 32-58.

Goldman, D. 2000. 'Consumer Republic', AdWeek, 41(24): 15-16.

Hoeffler, S. and K.L. Keller. 2002. 'Building Brand Equity through Corporate Societal Marketing', Journal of Public Policy \& Marketing, 21(1): 78-89.

Jayakody, J.A.S.K. and W.M.A. Sanjeewani. 2006. 'The Impact of Salesperson Transformational Leadership Behavior on Customer Relationship Marketing Behavior', International Journal of Bank Marketing, 24 (7): 461-74.

Kanungo, R.N. and M. Mendonca. 1996. Ethical Dimensions of Leadership. Thousand Oaks, CA: Sage Publications.

Keeley, M. 1995. 'The Trouble with Transformational Leadership: Toward a Federalist Ethic for Organizations', Business Ethics Quarterly, 5(1): 67-96.

Kotter, J.P. 1995. 'Leading Change: Why Transformational Efforts Fail', Harvard Business Review, 73(2): 59-67.

Krishnan, V.R. 2005. 'Transformational Leadership and Outcomes: Role of Relationship Duration', Leadership and Organization Development Journal, 26(6): 442-57.

Lafferty, B.A. and R.E. Goldsmith. 1999. 'Corporate Credibility's Role in Consumers' Attitudes and Purchase Intentions when a High versus a Low Credibility Endorser is used in the Ad', Journal of Business Research, 44(2): 109-16.

Leithwood, K., D. Tomlinson and M. Genge. 1996. 'Transformational School Leadership', in K. Leithwood, J. Chapman, D. Corson, P. Hallinger and A. Hart (eds), International Handbook of Educational Leadership and Administration, pp. 785-840. Dordrecht: Kluwer.

Marin, L. and S. Ruiz. 2007. "“I Need You Too!” Corporate Identity Attractiveness for Consumers and the Role of Social Responsibility', Journal of Business Ethics, 71(3): 245-60.

McAlexander, J.H., J.W. Schouten and H.F. Koening. 2002. 'Building Brand Community', Journal of Marketing, 66(1): 38-54. 
McGuire, J.B., A. Sundgren and T. Schneeweis. 1988. 'Corporate Social Responsibility and Firm Financial Performance', Academy of Management Journal, 31(4): 854-72.

McWilliam, G. 2000. ‘Building Stronger Brand through Online Communities', Sloan Management Review, 41(3): 43-54.

Mehta, P. and V.R. Krishnan . 1999. 'Role of Leadership in Building a Sense of Community: A Preliminary Investigation', Management and Labour Studies, 24(4): 236-42.

Menguc, B., S. Auh and E. Shih. 2007. 'Transformational Leadership and Market Orientation: Implications for the Implementation of Competitive Strategies and Business Unit Performance', Journal of Business Research, 60(4): 314-21.

Miller, B.A. 2002. 'Social Initiatives can Boost Loyalty', Marketing News, 36(21): 14-15.

Moir, L. 2001. 'What Do We Mean by Corporate Social Responsibility?', Corporate Governance, 1(2): 16-22.

Muniz, A.M. Jr. and T.C. O'Guinn. 2001. 'Brand Community', Journal of Consumer Research, 27(4): 412-32.

Murray, K.B. and C.M. Vogel. 1997. 'Using a Hierarchy of Effects Approach to Gauge the Effectiveness of Corporate Social Responsibility to Generate Goodwill toward the Firm: Financial versus Nonfinancial Impacts', Journal of Business Research, 38(2): 141-59.

Owen, C.L. and R.F. Scherer. 1993. 'Social Responsibility and Market Share', Review of Business, 15(1): 11-16.

Pawar, B.S. and K.K. Eastman. 1997. 'The Nature and Implications of Contextual Influences on Transformational Leadership: A Conceptual Examination', Academy of Management Review, 22(1): 80-109.
Prykop, C. and M. Heitmann. 2006. 'Designing Mobile Brand Communities: Concept and Empirical Illustration', Journal of Organizational Computing \& Electronic Commerce, 16 (3/4): 301-23.

Schouten, J.W. and J.H. McAlexander. 1995. 'Subcultures of Consumption: An Ethnography of the New Bikers', Journal of Consumer Research, 22(1): 43-61.

Shamir, B., R.J. House and M.B. Arthur. 1993. 'The Motivational Effects of Charismatic Leaders: A Selfconcept Based Theory', Organizational Science, 4: 577-94.

Smith, S.M. and D.S. Alcorn. 1991. 'Cause Marketing: A New Direction in the Marketing of Corporate Responsibility', Journal of Consumer Marketing, 8(3): 19-35.

Solomon, R. and K. Hansen. 1985. It's Good Business. New York: Antheneum.

Ullmann, A.A. 1985. 'Data in Search of a Theory: A Critical Examination of the Relationships among Social Performance, Social Disclosure, and Economic Performance of the U.S. firms', Academy of Management Review, 10(3): 540-57.

Wartick, S.L. and P.L. Cochran. 1985. 'The Evolution of the Corporate Social Performance Model', Academy of Management Review, 10(4): 758-69.

Weber, M. [1922] 1978. Economy and Society. Berkeley: University of California Press.

Willmott, M. 2003. 'Citizen Brands: Corporate Citizenship, Trust, and Branding', Journal of Brand Management, 10(4/5): 362-69.

Wood, D.J. 1991. 'Corporate Social Performance Revisited', Academy of Management Review, 16(4): 691-718.

\section{APPENDIX}

The six dimensions of 'Brand Community' comprise the following items:

\section{Shared culture}

a. I feel there is a strong sense of 'group identity' or 'we-ness' amongst persons associated with the brand. b. I feel I can easily relate to others associated with the brand.

c. I feel a sense of kinship with other people associated with the brand.

d. I would like to be a member of an informal club formed around the brand.

e. I feel that I get many opportunities to interact with others associated with the brand. 


\section{Moral responsibility}

a. I would defend the brand if someone is criticizing it.

b. I feel that the firm acts with integrity.

\section{Rituals and traditions}

a. I like to share brand success stories (advertisements etc.) with others.

b. I like to talk about my personal experiences of the brand with others.

c. I feel certain events associated with the brand are guided by traditions.

\section{Product}
a. I love the product.
b. I am proud of the product.
c. I enjoy the product.

\section{Brand}

a. I value the rich history of the brand.

b. The brand is my favorite.

c. I would recommend the brand to my friends.

d. I would go for a repeat purchase of the same brand.

e. I perceive the brand as the ultimate in quality.

f. I feel the urge to express my opinion on issues related to the brand.

\section{Firm}

a. I feel the organization cares about my opinion.

b. I feel the organization understands my needs.

c. I feel that the firm takes my feedback seriously.

d. I feel that the organization shares information with me.

e. I am satisfied with the formal/informal forums provided by the firm to voice my opinions. 